\title{
The Transposition of the Non-Financial Reporting Directive in the UK, France and Italy*
}

\author{
Selena Aureli ${ }^{* *}$, Elisabetta Magnaghi $^{* * *}$, Federica Salvatori ${ }^{* * * *}$
}

\begin{abstract}
The aim of this study is to investigate how EU Member States used their discretion in transposing EU Directive n. 2014/95/EU. The Directive provided the opportunity to achieve similar levels of companies' transparency on social and environmental matters, as well as increasing trust and encouraging more sustainable corporate behaviors. The comparison of the transposition laws in France, Italy, and the UK indicates that significant differences shape company obligations at the country level.
\end{abstract}

Keyword: Harmonization; Sustainability; NF Directive; Non-financial Information; EU Directive n. 2014/95/EU; Global Markets

\section{Non-financial Reporting Directive}

About 60 years ago, organizations started providing voluntary reporting as a means of demonstrating awareness of their own responsibility towards society and the environment with the objective of legitimizing their behaviors and obtaining the consensus of financial markets. Over time, growing societal pressures and expectations resulted in the increase and evolution of sustainability reporting (Brondoni, 2014), as well as the development of standards and guidelines (Salvioni and Bosetti, 2014). This type of reporting is now common practice among large companies (KPMG, 2013).

The disclosure of environmental, social, and governance (ESG) information was mainly provided on a voluntary basis. More recently, after many years of laissezfaire, regulation began to be deemed necessary (UNEP, 2010; UN, 2013). Therefore, the accountability demand was at times satisfied by means of regulations or listing requirements (Salvioni and Bosetti, 2014). Some EU Member States can be considered pioneers of this type of regulation, such as France (Law of New Economic Regulations issued in 2001, followed by Grenelle I and Grenelle II) and Denmark (Danish Financial Statements Act issued in 2001). Others intervened as a result of the 2003/51/EU Directive (Accounts Modernisation Directive), which is

\footnotetext{
* The Authors: S. Aureli § 3, E. Magnaghi §1, F. Salvatori §§ 2, 5. All authors equally contributed to $§ 4$.

** Assistant Professor, University of Bologna (selena.aureli@ unibo.it)

*** Associate Professor, Université Catholique de Lille (elisabetta.magnaghi@univ-catholille.fr)

***** Lecturer, University of Leicester (fs166@le.ac.uk)
} 
one of many initiatives put in place by the EU to promote the disclosure of nonfinancial information (Hibbitt and Collison, 2004; Albareda et al., 2007).

Despite the evolution in ESG reporting, the EU Commission's consultation on Non-Financial Disclosure (EC, 2011) acknowledged the inadequacy of current reporting practices to satisfy the information needs of markets. Lack of transparency and the coexistence of different legal regimes led the EU to issue the 2014/95/EU Directive (henceforth "NF Directive"), which obliges certain large public undertakings and groups to provide a non-financial statement commencing on or after 1 January 2017. The NF Directive explicitly states the intention of achieving similar high levels of transparency across the EU by allowing each Member State "high flexibility of action in order to take account of the multidimensional nature of corporate social responsibility (CSR) and the diversity of the CSR policies implemented by businesses".

Leaving many options to Member States implies that individual national interests may prevail on achieving the success of harmonization (Evans and Nobes, 1998). While one country may simply opt for a normalizing process and passively transpose the directive mandate into its own national legal system, another country could amend the mandate to fit the particulars of its own internal environment. The NF Directive could be a game changer, although a number of issues have already been identified (e.g., Johansen, 2016). As the EU directives impact on companies only at the transposition stage, and transposition will then impact on the actual implementation, this research intends to investigate how discretion has been used locally. The aim is to understand the differences in transposition of the NF Directive in three European countries and whether divergences may jeopardize the original intent of the NF Directive. This is the first stage of a wider project aiming to understand how differences in regulations may be linked to previous existing norms and business practices.

As the transposition of the NF Directive is a recent occurrence, its investigation is still limited. This paper contributes to the existing literature on corporate disclosure and formal harmonization in general, and to the debate around non-financial reporting in particular. The results can be beneficial at a regulatory level because they provide first insights about the potential outcome of the European intervention for the legislator.

\section{The Need of Regulating Non-financial Disclosure and the Issue of NF Directive}

Governments conceive regulation on ESG aspects as the means to respond to increasing accountability demands from stakeholders and a soaring interest by investors on CSR aspects (EY, 2014; Cohen et al., 2015). However, there are competing views about the effectiveness and impacts of regulation.

Those in favor of regulation argue that mandatory sustainability reporting limits the use of ESG disclosure as a legitimation strategy (Lewis and Unerman, 1999) and would therefore allegedly improve transparency, credibility of reporting and standardization as well as comparability, legal certainty and corporate culture (UNEP, 2010). Similarly, Boyer-Allirol (2013) argues that regulating CSR reporting would help overcome the shortcomings of voluntary reporting; in her opinion, only by prescribing a certain quality and quantity of information as well as 
auditing can the ESG information be credible enough to be taken into account by investors in their decisions. Bernardi and Stark (2016) suggest that the mandatory preparation of integrated reports in South Africa strengthens the relationship between ESG disclosure and analyst forecast accuracy. Regulation may favor greater transparency that reduces information asymmetries leading to higher market efficiency and lower cost of capital (e.g., Dhaliwal et al., 2011; Goss and Robert, 2011).

Others take the opposite view on the need of regulation. For example, with reference to environmental information, Luque-Vilchez and Larrinaga (2016) use the Spanish regulatory case to show how regulation did not impact the number of reports and marginally increased the reporting quality. They argue that this may anticipate the outcomes of the NF Directive. Bebbington et al. (2012) show how regulation in Spain was not enough to create a norm because it lacked normativity, which is the result of some actors' agency and structural elements such as the existence of previous norms. Chauvey et al. (2015) build on the work of Bebbington et al (2012) and use the French case to argue that CSR disclosure requirements were moving toward normativity, but not leading to an improvement in information quality.

Recently, the European Commission (EC, 2013) highlighted the shortcomings of voluntary reporting. Corporate disclosure was described as often unbalanced, inaccurate, inconsistent, and not comparable. Companies used Key Performance indicators (KPIs) poorly and provided insufficient information about significant aspects such as risk management, human rights, and corruption matters. Many studies also highlight how CSR reports can be a symbolic management practice and how the quality of reporting can be quite poor (e.g., Boiral, 2013; Michelon et al, 2015; Merkl-Davies and Brennan, 2007).

On multiple occasions, the EU highlighted the need for a change (for example in the European Parliament resolution of 6 February 2013 on CSR - 2012/2097 INI). Therefore, the NF Directive was issued on 22 October 2014 to set specific requirements for large undertakings (public-interest entities having more than 500 employees) about the disclosure of ESG information in a document named "nonfinancial statement". Provisions are made in relation to the content, structure, form, and diffusion to the public and in relation to the verification by third parties. However, some aspects (i.e., the verification of the content of the non-financial statement) are indicated as optional to ensure that Member States are free to choose the most appropriate forms and means to achieve the objectives set by an EC Directive. In this sense, the NF Directive leaves discretion to Member States meaning that they have room to maneuver in implementing the Directive (GreenCowles et al, 2001).

Moreover, the NF Directive does not provide stringent and detailed rules for disclosure, but it simply states that non-financial information should be published "to the extent necessary to understand the evolution of the business, the results and the situation of the company as well as the impact of its activities". This "minimum harmonisation" approach to European legislation, which allows Members States to decide whether to apply more stringent regulations or not, does not always lead to minimum impacts on national contexts. For example, Jeppesen and Loft (2011) show how the implementation of the European Eight Directive in Denmark disturbed the balance within the auditing profession and triggered a conflict between state-authorized and registered auditors over the statutory audit 
jurisdiction. Hence, the transposition of European directives into country members' legislation represents a challenging step that academics have just started to investigate (Szabó and Sørensen, 2017; Jeffery, 2017).

The focus of this paper is on formal implementation of directives, which relates to transposition of a Directive into a national law. Its investigation is important because formal harmonization (or de jure harmonization) is a crucial driver of material (or practical) harmonization, which relates to the compliance by regulated subjects (Tay and Parker, 1990; Rahman et al, 1996) and because "it is only possible in the first place to harmonise standards, not environmental or cultural factors nor accounting practices for all listed companies in one country" (D'Arcy, 2001). However, formal implementation not always leads to practical implementation (Versluis, 2007). Practices may converge when rules don't, and vice versa (e.g., Ball et al., 2003; Mahoney, 2009).

At the stage of formal implementation, the Member States use a variety of techniques for transposing directive provisions into national law, like copying parts of the text from a directive in a new national regulation, transposing with minor or major terminology changes or other adjustments and opting for elaboration and/or formulation. Over-implementation and under-implementation are also possible (Dimitrakopoulos, 2001). In this sense, discretion can be used to set requirements that exceed the EU law (gold plating) or not.

A variety of factors could explain differences in transposition. Some studies focus on legal, administrative, and political variables (e.g., Mastenbroek, 2003, Bursens, 2002; Dimitrakopoulos, 2001), domestic politics (e.g., Dimitrova and Steunenberg, 2000; Borzel and Risse, 2003) or poor quality and clarity of the Directives (e.g., Knill and Lenschow, 1998; Dimitrakopoulos, 2001). Others investigated the degree of fit or misfit between the European legislation and the domestic situation building on the assumption that Member States try to minimize the cost of institutional adaptation caused by the transposition (Borzel, 2003; Heritier, 1995). However, Falkner et al. (2007) found that domestic governments may welcome a high degree of 'misfit' as an opportunity to introduce a positive change.

Since the NF Directive allows Member States to choose the most appropriate forms and means to achieve the desired outcome, this paper aims to identify differences in the transposition of the EU by carrying out a country-by-country comparison of the individual national legislations that introduce the new obligations on ESG disclosure. The diversity policy also introduced by the NF Directive is not object of investigation in this research.

\section{Data and Methods}

In order to explore the differences in transposition of EU NF Directive, we focused our analysis on UK, France, and Italy for a combination of reasons. Since our goal is to understand whether divergences in transposition may jeopardize the achievement of the original intent of the NF Directive, we considered the EU Member States having a number of infringements cases in the last 5 years (from 2012 to 2016) higher than total average (EC, 2016) Those are 13 out of 28 Member States (Table 1). The higher the number of infringements, the greater is the attitude of the national government to not ensure timely and correct transposition of EU law. Among the 13 Member States, we focused on those that have been more 
investigated by previous academic studies for their peculiarities in national transpositions and whose national language is known by the authors.

Table 1: Number of infringement cases in EU-28 Member States

\begin{tabular}{|l|c|c|c|c|c|c|}
\hline & $\mathbf{2 0 1 2}$ & $\mathbf{2 0 1 3}$ & $\mathbf{2 0 1 4}$ & $\mathbf{2 0 1 5}$ & $\mathbf{2 0 1 6}$ & average 5 years \\
\hline Croatia & 0 & 2 & 16 & 28 & 69 & $\mathbf{2 3}$ \\
Latvia & 30 & 33 & 37 & 44 & 58 & $\mathbf{4 0}$ \\
Malta & 44 & 34 & 31 & 44 & 50 & $\mathbf{4 1}$ \\
Denmark & 44 & 45 & 46 & 38 & 62 & $\mathbf{4 7}$ \\
Estonia & 48 & 50 & 32 & 52 & 60 & $\mathbf{4 8}$ \\
Lithuania & 44 & 39 & 39 & 49 & 79 & $\mathbf{5 0}$ \\
Netherlands & 47 & 49 & 42 & 49 & 65 & $\mathbf{5 0}$ \\
Slovakia & 40 & 53 & 49 & 61 & 56 & $\mathbf{5 2}$ \\
Sweden & 42 & 42 & 40 & 65 & 72 & $\mathbf{5 2}$ \\
Ireland & 47 & 48 & 51 & 50 & 89 & $\mathbf{5 7}$ \\
Luxemburg & 46 & 54 & 53 & 59 & 87 & $\mathbf{6 0}$ \\
Finland & 64 & 56 & 45 & 49 & 88 & $\mathbf{6 0}$ \\
Czech Republic & 49 & 43 & 56 & 63 & 93 & $\mathbf{6 1}$ \\
Hungary & 68 & 58 & 70 & 55 & 93 & $\mathbf{6 9}$ \\
Bulgaria & 59 & 55 & 91 & 59 & 82 & $\mathbf{6 9}$ \\
Slovenia & 55 & 74 & 76 & 76 & 86 & $\mathbf{7 3}$ \\
UK & 85 & 73 & 74 & 64 & 80 & $\mathbf{7 5}$ \\
Austria & 75 & 68 & 79 & 63 & 106 & $\mathbf{7 8}$ \\
Romania & 59 & 68 & 105 & 72 & 92 & $\mathbf{7 9}$ \\
Cyprus & 67 & 72 & 71 & 85 & 112 & $\mathbf{8 1}$ \\
Portugal & 101 & 75 & 75 & 73 & 135 & $\mathbf{9 2}$ \\
Germany & 72 & 81 & 95 & 110 & 112 & $\mathbf{9 4}$ \\
France & 77 & 92 & 97 & 102 & 116 & $\mathbf{9 7}$ \\
Poland & 100 & 83 & 97 & 100 & 112 & $\mathbf{9 8}$ \\
Spain & 107 & 110 & 110 & 99 & 125 & $\mathbf{1 1 0}$ \\
Belgium & 113 & 98 & 120 & 93 & 130 & $\mathbf{1 1 1}$ \\
Greece & 103 & 101 & 123 & 114 & 122 & $\mathbf{1 1 3}$ \\
Italy & 135 & 132 & 111 & 107 & 85 & $\mathbf{1 1 4}$ \\
\hline 28 Member States total average & & & & $\mathbf{7 1}$ \\
\hline
\end{tabular}

Source: own elaboration on EU 2012-2016 data (EU, 2016)

Equally important in the selection of countries is the different understanding of CSR concept and diverse initiatives taken by the respective national governments on socio-environmental disclosure before the issue of the NF Directive. National differences, which are linked to the different social, cultural, and political context, are important to consider as they drive governments to adjust the Directive to fit the particulars of the local context and generate obstacles to harmonization (Albareda et at., 2007). As stated by Baker (2014), if the national differences are based on 
established laws and historical traditions, then expectations for increased regulatory harmonization may be difficult to achieve.

In France (where there is a sound welfare state), companies are expected to take over social responsibility for sustainable development. Thus, the State is used to promote or require CSR by law issuing detailed regulations. Moreover, France is among the EU countries that first made experiments with social reporting (the 'bilan social' was a legal requirement in France since 1977). In the UK, CSR initiatives emerged as company voluntary actions and the Government acted as facilitator to provide incentives for CSR activities. Moreover, the English legal tradition states that only principles are laid down while the rest is supplemented by managerial discretion (Arnold and Matthews, 2002). Italy has fewer years of experience on CSR. Its Government introduces initiatives later because it preferred creating discussion groups and committees to create consensus on CSR (Contrafatto and Rusconi, 2005).

In order to compare national transpositions, we started from a textual analysis of the NF Directive articles. Articles refer to regulatory choices or regulations set with reference to different aspects, i.e., the list of topics or content to be disclosed, the company scope of application, the application of principles like the "company or explain" rule. Then, we searched for regulation of the same aspects in the national laws transposing the Directive. However, the magnitude and implications of possible differences in national legislations can be better appreciated if regulatory choices are investigated in relation to what the NF Directive intends to achieve. Analyzing how the national transpositions fit into the NF Directive objectives may be predictive of the actual outcome of the NF Directive.

We used the Preamble to the Directive to identify the intent of the legislator, which is, to be concise, to improve transparency (1) and trust (2) and ultimately foster a change toward a more sustainable behavior (3). We drew from teleological argumentation in legal theory and structuralism to interpret the regulatory choices in light of these three key objectives, as they are two common interpretation methods in the EU legal order (Barak, 2005; Baratta and Carli, 2014). We followed the textual meaning where possible and used a purposive approach where the wording was not clear. Often used in case law of the European Court of Justice, this method leads to interpreting laws in light of the finalities of EU provisions.

In addition, we recurred to the literature on financial reporting and sustainability reporting to clarify how a regulatory choice informs the characteristics or qualities that information should have to favor transparency, trust, and a responsible behavior. These characteristics represent sub-objectives necessary to achieve the higher-end goals of the NF Directive.

This process of interpretation resulted in the grid of Table 2. We applied this grid in the analysis of the SI2016 No. 1245 which amended the UK Companies Act 2006, the Italian Legislative Decree No. 254/2016 and the Decree No. 2017-1265 of August 9, 2017 which modified the Commercial Code, previously already modified by laws as Grenelle 1 No. 2009-967 of August 3, 2009 and Grenelle 2, No. 2010-788 of July 12, 2010. 
(C) SYMPHONYA Emerging Issues in Management, n. 1, 2018

symphonya.unimib.it

Table 2: Grid of Analysis

\begin{tabular}{|c|c|c|}
\hline OBJECTIVES & SUB-OBJECTIVES & REGULATORY CHOICES (mandatory requirements in Italics) \\
\hline \multirow[t]{18}{*}{$\begin{array}{l}1 . \\
\text { TRANSPA- } \\
\text { RENCY }\end{array}$} & \multirow[t]{6}{*}{$\begin{array}{l}\text { COMPLETE- } \\
\text { NESS }\end{array}$} & $\begin{array}{l}\text { a) List of topics (minimum requirement: } 1 . \text { Environmental } \\
\text { matters; } 2 . \text { Social matters; } 3 \text {. Employee matters, 4. Respect for } \\
\text { human rights; } 5 . \text { Anti-corruption and bribery matters) }\end{array}$ \\
\hline & & $\begin{array}{l}\text { b) Items (1. Policies, including any due-diligence process; } 2 . \\
\text { Outcomes; 3. Risks; 4. Business model; 5. Non-financial key } \\
\text { performance indicators; 6. Framework chosen (if any) }\end{array}$ \\
\hline & & c) Further topics \\
\hline & & d) Further items \\
\hline & & e) Further specifications \\
\hline & & $\begin{array}{l}\text { f) Omit information if does not prevent a fair and balanced } \\
\text { understanding }\end{array}$ \\
\hline & RELEVANCE & $\begin{array}{l}\text { Reference to the concept of materiality (meant as "necessary } \\
\text { for an understanding of the undertaking's development, } \\
\text { performance, position and impact of its activity") }\end{array}$ \\
\hline & \multirow[t]{2}{*}{ CLARITY } & $\begin{array}{l}\text { a) Additional explanations and references to financial } \\
\text { statements }\end{array}$ \\
\hline & & b) Clear explanations for not pursuing ESG policies \\
\hline & \multirow[t]{3}{*}{$\begin{array}{l}\text { COMPARABI- } \\
\text { LITY }\end{array}$} & $\begin{array}{l}\text { a) Comparison with peers (scope) (1.500 employees } \\
\text { threshold; } 2 \text {. Further thresholds; } 3 \text {. Wider scope of application) }\end{array}$ \\
\hline & & b) Comparison with previous years \\
\hline & & c) Flexibility to choose reporting frameworks \\
\hline & CONSISTENCY & a) Disclosure of changes/differences in policies \\
\hline & \multirow[t]{3}{*}{ ACCESSIBILITY } & a) Within the management report \\
\hline & & $\begin{array}{l}\text { b) In the country-specific report for ESG aspect (Strategic } \\
\text { Report) }\end{array}$ \\
\hline & & c) Media channels (e.g., website) \\
\hline & \multirow[t]{2}{*}{ TIMELINESS } & a) Disclosure with the annual report \\
\hline & & b) Within 6 months from the end of year \\
\hline \multirow[t]{2}{*}{ 2. TRUST } & RELIABILITY & a) Audit on the presence of the NF statement \\
\hline & and ACCURACY & $\begin{array}{l}\text { b) Assurance on the content of the NF statement } \\
\text { c) Further assurance requirements } \\
\text { d) Audit carried out by statutory auditors and audit firms } \\
\text { e) Assurance carried out by other independent assurance } \\
\text { providers }\end{array}$ \\
\hline \multirow{2}{*}{$\begin{array}{l}\text { 3. CHANGE } \\
\text { IN CSR } \\
\text { PRACTICES }\end{array}$} & ENFORCEMENT & Penalties for companies not disclosing \\
\hline & $\begin{array}{l}\text { BOARD } \\
\text { INVOLVEMENT }\end{array}$ & $\begin{array}{l}\text { Board responsibility for ensuring that NF statement is } \\
\text { prepared, published and compliant }\end{array}$ \\
\hline
\end{tabular}

Source: Own elaboration

Transparency

The NF Directive does not define the concept of transparency. However, some indication is given by the EC (2013) when it says that "information is not sufficiently material, accurate, timely, clear, comparable, and reliable". We used then these characteristics and others mentioned in the NF Directive (e.g., ease of access and consistency) to interpret the EU provisions. Moreover, we relied on financial accounting literature, which states that reports or companies are transparent when they provide information that reflects all material aspects (Mulford and Comiskey, 2002; Roohani et al., 2009), the substance of events in a 
straightforward manner (McEwen, 2009) so that it is readily understandable by users (Barth and Schipper, 2008) and easily extracted and effectively used (Hunton et al., 2006). In summary, information is transparent when it provides a clear, concise, and balanced information on relevant aspects (Bushman et al., 2004).

Transparency includes the concept of completeness (Dubbnik et al., 2008) and relevance. GRI, for example, defines transparency as "the complete disclosure of information on the topics and indicators required to reflect impacts and enable stakeholders to make decisions." (GRI, 2011, p. 6). However, the NF Directive does not explicitly define the concept of relevance, but rather limits the provision of non-financial information to the extent necessary for "understanding of the undertaking's development, performance, position and impact of its activity". Similarly, there is no definition for completeness. The NF Directive sets a minimum requirement to disclose the policies, the effects of those policies, and principal risks related to a common set of information ("related to environmental, social and employee matters, respect for human rights, anti-corruption and bribery matters") while allowing for additional disclosure on firm-relevant topics.

Transparency can be enhanced by comparability (Barth and Schipper, 2008). Comparability occurs when similar companies apply the same rules, indicate previous performance and apply consistent disclosure from one period to another. Comparability is also related to uniformity (Wolk et al., 2008). Uniformity is when similar events are treated similarly by different companies and it is favoured by the enforcement of common standards and practices (Cole et al., 2012). The NF Directive has made no standard or format mandatory, although some authors suggest that imposing a framework like GRI guidelines would have helped regulatory bodies enhance the comparability of companies' CSR reports (Matuszak and Rózanska, 2017). Member States are left to decide whether companies shall adopt "national, Union-based or international frameworks" or not. Thus, national legislators and/or standard-setters have the opportunity to undermine the harmonizing effect of the Directives (Aisbitt, 2008). This contrasts with the approach followed in the previous IV EU Directive. In that case, the adoption of a common layout or formats of financial statements generated uniformity and represented the most successful area of harmonization achieved by the European Union (Walton, 1992).

Another key characteristic that favors transparency is accessibility, which is related to the media used for communication. CSR information can be diffused through several means: corporate reporting, press releases, annual meetings open to public, websites, and other internet channels etc. The NF Directive requires companies to include the non-financial statement either in the management report or alongside it. Thus, a company can alternatively prepare a separate report covering ESG information as allowed by Italy and Poland (Matuszak and Rózanska, 2017). In this case, it has to be made publicly available on the undertaking's website and cross-referenced in the management report. As the management report is directed at investors and is not often read by consumers, employees, and other user groups different than shareholders, this alternative would potentially enhance the accessibility to a larger audience as well as increase the detail and extent of the information provided (Davis et al., 2003).

Lastly, information has to be accessible in a timely manner in order to be part of the users' decision-making process. The internet is a communication channel that is more timely and useful to decision makers compared to paper-based reporting 
(Bolivar, 2009). Therefore, policy makers should focus on timelier reporting of both positive and negative performance as one of the means to level the playing field on CSR performance (Cho et al., 2013).

Trust

The NF Directive also intends to increase trust. Requiring the auditing of the nonfinancial statement may increase reliability and truthfulness. De Villiers and Van Staden $(2010,2012)$ found that shareholders value disclosure of environmental information and they want it to be compulsory and audited. Assurance of sustainability information is an important aspect and is gaining momentum (CorporateRegister, 2008; Simnett et al, 2009). Boyer-Allirol (2013) argues that it is one of the fundamental conditions for ESG information to be credible enough to be taken into account by investors in their decisions. However, the NF Directive gives Member States the discretion to choose whether to verify the content of reports by an independent assurance service provider.

\section{Adoption of CSR practices}

The NF Directive sits under the umbrella of public policies aimed at leveraging CSR. This represents the end outcome of making non-financial disclosure mandatory in the EU. As stated by Cantino and Cortese (2017) with reference to the NF Directive, "it is not just a matter of designing, providing, and implementing reporting tools... the aim is to achieve higher purposes" like promoting the development of businesses that are more ethical, social, and environmentaloriented. Requiring mandatory transparency on non-financial aspects is held to encourage companies to improve monitoring and management of performance and increase their commitment to CSR or responsible behaviors (Stone et al., 2004; Hamann, 2004; Boston and Lempp, 2011).

However, the success of regulation depends on both enforcement and implementation. While implementation is ongoing, the regulatory choices in terms of enforcement can be a useful dimension to consider (Leuz, 2010). Past studies concentrate on two main factors: the role of sanctions for non-compliance to CSR disclosure set by governments as a means to generate more attention to sustainability (Chelli et al., 2014) and the involvement of the Board that could accelerate the diffusion of a culture of sustainability within the organization (FriasAceituno et al., 2013). Involvement could be increased by holding the Board responsible for the content of the non-financial statement. The Board may be recommended to set up a committee dedicated to oversight of sustainability issues (as for the Risk Committee). However, the NF Directive doesn't provide any detail on the matter.

\section{Results from the International Comparison}

The grid of analysis has been applied in the examination of national transpositions. Results are reported in tables by intended aim of the NF Directive to show similarities and differences among countries.

\section{Transparency}


In relation to completeness, Table 3 shows that each country didn't go beyond the minimum requirement set by the EU Directive. They merely transposed the list of topics and items to disclose as written in the EU Directive.

Table 3: Transparency

\begin{tabular}{|c|c|c|c|c|}
\hline $\begin{array}{l}\text { SUB- } \\
\text { OBJECTIVES }\end{array}$ & $\begin{array}{l}\text { REGULATORY CHOICES (mandatory } \\
\text { requirements in Italics) }\end{array}$ & $\mathbf{U K}$ & FR & IT \\
\hline \multirow{17}{*}{ COMPLETENESS } & a) List of topics (minimum requirement) & & & \\
\hline & 1. Environmental matters & yes & yes & yes \\
\hline & 2. Social matters & yes & yes & yes \\
\hline & 3. Employee matters & yes & yes & yes \\
\hline & 4. Respect for human rights & yes & yes & yes \\
\hline & 5. Anti-corruption and bribery matters & yes & yes & yes \\
\hline & b) Items (including regulatory framework) & & & \\
\hline & 1.Policies, including any due-diligence process & yes & yes & yes \\
\hline & 2. Outcomes & yes & yes & yes \\
\hline & 3. Risks & yes & yes & yes \\
\hline & 4. Business model & yes & yes & yes \\
\hline & 5. Non-financial key performance indicators & yes & yes & yes \\
\hline & 6. Framework chosen (if any) & yes & yes & yes \\
\hline & c) Further topics & no & no & no \\
\hline & d) Further items & no & no & no \\
\hline & e) Further specifications & yes & yes & yes \\
\hline & $\begin{array}{l}\text { f) Omit information if does not prevent a fair and } \\
\text { balanced understanding }\end{array}$ & yes & yes & yes \\
\hline RELEVANCE & Reference to the concept of materiality & yes & yes & yes \\
\hline \multirow[t]{2}{*}{ CLARITY } & $\begin{array}{l}\text { a) Additional explanations and references to financial } \\
\text { statements }\end{array}$ & yes & no & yes \\
\hline & b) Clear explanations for not pursuing ESG policies & yes & yes & yes \\
\hline \multirow{6}{*}{$\begin{array}{l}\text { COMPARABI- } \\
\text { LITY }\end{array}$} & a) Comparison with peers (scope) & & & \\
\hline & 1. 500 employees threshold & yes & yes & yes \\
\hline & 2. Further thresholds & no & yes & yes \\
\hline & 3. Wider scope of application & no & yes & no \\
\hline & b) Comparison with previous years & no & yes & yes \\
\hline & c) Flexibility to choose reporting frameworks & yes & yes & yes \\
\hline CONSISTENCY & a) Disclosure of changes/differences in policies & no & no & yes \\
\hline \multirow{3}{*}{ ACCESSIBILITY } & a) Within the management report & no & yes & yes \\
\hline & $\begin{array}{l}\text { b) In the country-specific report for ESG aspect } \\
\text { (Strategic Report) }\end{array}$ & yes & no & no \\
\hline & c) Media channels (e.g., website) & no & no & yes \\
\hline \multirow{2}{*}{ TIMELINESS } & a) Disclosure with the annual report & yes & yes & yes \\
\hline & b) Within 6 months from the end of year & no & no & yes \\
\hline
\end{tabular}

However, the level of similarity in terms of topics is deceitful. Table 4 shows that the UK remained pretty much silent, that is to say they gave very little specification in relation to topics or items are provided while France imposes a detailed list of requirements. The UK approach may have not come as a surprise as we would expect further guidance to be left in the hands of the FRC rather than the legislator. France took the complete opposite stance, showing a strong regulatory approach by listing 42 aspects on the basis of those included in Grenelle II. Italy seems to sit in between; it regulated less than France, but shared most of the aspects with the French legislation. 
Table 4: Further National Specifications

\begin{tabular}{|c|c|c|c|}
\hline & UK & FR & IT \\
\hline \multicolumn{4}{|l|}{ Environmental matters } \\
\hline 1. The use of energy resources & no & yes & yes \\
\hline 2. The use of water resources; & no & yes & yes \\
\hline 3. Emissions of greenhouse gases & no & yes & yes \\
\hline 4. Polluting emissions & no & yes & yes \\
\hline 5. The impact on the environment & yes & yes & yes \\
\hline 6. Impact on health and security & no & no & yes \\
\hline 7. Further requirements on specific items & no & yes & no \\
\hline 8. Environmental policies & no & yes & no \\
\hline \multicolumn{4}{|l|}{ Employees matters } \\
\hline 1. Gender equality/equality of treatment & no & yes & yes \\
\hline 2. Implementation of international conventions on employee rights & no & yes & yes \\
\hline 3. Social dialogue/social relations & no & yes & yes \\
\hline 4. Employment & no & yes & no \\
\hline 5. Organization of work: & no & yes & no \\
\hline 6. Health and safety & no & yes & no \\
\hline 7. Training policy & no & yes & no \\
\hline \multicolumn{4}{|l|}{ Social matters } \\
\hline 1. Commitment for local sustainable development and local populations & no & yes & no \\
\hline 2. Relations with local stakeholders & no & yes & no \\
\hline 3. Partnership and sponsorship actions for local development & no & yes & no \\
\hline 4. Inclusion in the purchasing policy of social and environmental issues & no & yes & no \\
\hline 5. Measures for the health and safety of consumers & no & yes & no \\
\hline \multicolumn{4}{|l|}{ Human rights } \\
\hline 1. Policies to prevent violations of human rights & no & yes & yes \\
\hline 2. Fight against discrimination & no & yes & yes \\
\hline 3. Protection of labor force's human rights & no & yes & no \\
\hline \multicolumn{4}{|l|}{ Anti-corruption and bribery matters } \\
\hline 1. Fight against both active and passive corruption & no & yes & yes \\
\hline \multicolumn{4}{|l|}{ Risks } \\
\hline 1. Policies applied to risks & no & yes & no \\
\hline 2. Results of risk policies and KPIs related to risks & no & yes & no \\
\hline \multicolumn{4}{|l|}{ Non-financial KPIs } \\
\hline 1. KPIs have to be chosen in line with the reporting standard & no & no & yes \\
\hline 2. Adjustments or additional KPIs are possible & no & no & yes \\
\hline
\end{tabular}

In relation to environmental matters, France shares five of the six aspects mentioned in the Italian law (e.g., use of energy and water resources) and requires many more (e.g., certifications; provisions for environmental risks, protection of biodiversity). The UK makes only one specification and it is the only point in common with the other two countries. Similarly, with reference to employee matters, the UK makes no specification at all while the Italian law puts forward 3 aspects on this topic which France shares and then goes on to require an additional four items. In relation to social matters, both Italy and the UK do not to provide further specification while France mentions 5 types of information that should be disclosed. Finally, the UK again doesn't provide any further specification about human rights matters while Italy requires 3 specific kinds of information (for example the fight against discrimination), all of them shared with France who also 
added a further element to its list. Amongst all topics, anti-bribery and corruption seem to be overlooked.

With reference to the disclosure of items, the UK merely adheres to the NF Directive while France and Italy make further specifications but about different matters. France requires the disclosure of policies applied to risks, the results of those policies, and KPIs related to risks. In relation to KPIs, Italy requires companies to choose indicators in line with the reporting standards and allows both adjustments and additional KPIs.

Despite the cited requirements, the completeness of the information provided above can be restricted. All countries adopted the option of leaving companies the possibility of omitting information that when disclosed would damage the company itself. This 'safe harbor principle' involves a certain level of judgement and therefore subjectivity from members of the administrative body in deciding when and which information is prejudicial.

Information needs to be relevant to users. The NF Directive mentions the word "relevant" when indicating how companies should choose which risks and key performance indicators to disclose and it states that "a fair and balanced understanding of an entity's situation" is the condition limiting the possibility for companies to omit information to the public. However, as already highlighted by Jeffery (2017), it is not clear which information is deemed to be material and how the materiality test should be conducted with regard to the impact of principal risks. Member States kept the same terminology as the NF Directive without further indications nor requirements about, for example, the disclosure of processes and governance arrangements used to perform their materiality assessment.

In relation to clarity of the information, the NF Directive requires companies to include, where appropriate, additional explanations or references to the financial statements, however this requirement is not mentioned in the French legislation. All countries mandate to explain why policies are not pursued and use the concept of relevance (copying the wording of the NF Directive) without providing further explanations. Therefore, the requirements that may enhance clarity are very limited. More elements such as the proposal of using images, graphs etc. could have been included.

The objective of comparability in ESG disclosure is pursued through various requirements. First of all, information can be comparable only if companies of the same type produce the information. However, the company scope is different. While all countries transposed the requirement of producing a non-financial statement for public interest entities with more than 500 employees, Italy and France used additional thresholds to identify those who shall disclose. In addition, France includes some companies whose securities are not admitted to trading on a regulated market with a balance sheet of at least 100 million Euros or net turnover of 100 million Euros and 500+ employees.

Secondly, comparability and uniformity could be enhanced using the same framework or standard. However, the NF Directive left Member States the possibility of allowing the use of national, Union-based or international frameworks. All countries left companies free to use one or more or none, so no one imposed a particular framework over others. Lastly, only Italy and France require information related to topics and items to be comparable with the previous year's one. 
In terms of consistency, only Italy specifically requires companies to disclose changes in policies from one year to the other. The other legislations do not explicitly require the content nor the KPIs to be consistent over time.

Differences also refer to the ease of access. Italy and France require the inclusion of the non-financial statement within the management report, therefore whole of the information is published at the same time. However, Italy also allows (and it is the only case) the use of a separate report. To facilitate accessibility, the Italian legislation specifies that the management report needs to signpost to where to find the non-financial statement if it is not within management report. UK companies will locate the statement within the strategic report, which was the space already dedicated to non-financial disclosure. Regardless of where it is located, timeliness of information is crucial. In the UK and France, the information will be accessible when the annual reports are available. Italy specifies that those who use a separate report must either publish it online within 6 months from the date the balance sheet was published or attach it to the management report.

\section{Trust}

Table 5 shows that Italy and the UK permit audit as only it is carried out by statutory auditors and audit firms while France allows a wider range of assurance providers.

The UK Companies Act wasn't amended in reference to this aspect. The UK doesn't require any specific audit on the content of the statement. Italy and France's requirements are stricter than those of the NF Directive; in both cases assurance on the content of the statement is required making the information disclosed more reliable. France also requires auditors of companies exceeding certain thresholds to provide further information in the audit report. The report of the independent thirdparty organization includes: (a) A reasoned opinion on the conformity of the declaration with the provisions laid down and on the accuracy of the information provided, and b) The steps he has taken to carry out his verification mission.

Table 5: Trust

\begin{tabular}{|l|l|l|l|l|}
\hline \multicolumn{2}{|l|}{$\begin{array}{l}\text { SUB - } \\
\text { OBJECTIVES }\end{array}$} & UK & FR & IT \\
\hline \multirow{5}{*}{$\begin{array}{l}\text { RELIABILITY } \\
\text { and ACCURACY }\end{array}$} & $\begin{array}{l}\text { a) Audit on the presence of the NF statement } \\
\text { b) Audit on the content of the NF statement }\end{array}$ & yes & yes & yes \\
\hline $\begin{array}{l}\text { c) Further assurance requirements } \\
\text { firms }\end{array}$ & $\begin{array}{l}\text { no } \\
\text { e) Assurance carried out by other independent } \\
\text { assurance providers }\end{array}$ & yes \\
\hline
\end{tabular}

\section{Adoption of CSR practices}

The high-level purpose of the NF Directive is that of enhancing the culture of sustainability and CSR of businesses in Europe. With reference to the aspects that could favor such a change, only Italy explicitly stated penalties for not producing the non-financial statement (Table 6). In all countries, the Boards have the ultimate responsibility to ensure that the non-financial statement is drawn up and published according to the legal requirements set by the EU Directive. 
(C) SYMPHONYA Emerging Issues in Management, n. 1, 2018

symphonya.unimib.it

Table 6: Changes in CSR practices

\begin{tabular}{|l|llll|}
\hline \multicolumn{2}{|l|}{ SUB-OBJECTIVES } & UK & FR & IT \\
\hline 3.1. ENFORCEMENT & Penalties for non-disclosure & no & no & yes \\
\hline 3.2. BOARD INVOLVEMENT & Board responsibility & yes & yes & yes \\
\hline
\end{tabular}

\section{Discussion and Conclusions}

The NF directive aims to achieve similar high level of transparency across Europe, increase trust in the information provided and move toward a more sustainable economy. These objectives are pursued by minimum requirements and allowing for high flexibility of actions.

This research investigates how this discretion was used in the context of the objectives of the NF Directive. Results show an alignment when legal requirements are set by the EU and a spontaneous convergence of certain elements of disclosure, but also significant differences that could hinder the aims of the NF Directive. Differences in requirements for completeness, comparability, and clarity of information stand out and affect the achievement of similar level of transparency.

Alignment emerges when all countries require disclosure on the same matters as those listed by the NF Directive (e.g., social, environmental, employees) and all embraced the possibility of omitting information. Also, they all merely copied the Directive's wording to indicate which material information has to be disclosed, i.e. "information to the extent necessary for an understanding of the undertaking's development, performance, position, and impact of its activity". However, this 'copying-out approach', together with a lack of clarification of concepts, may lead to a de facto non-binding obligation as it happened with the disclosure of environmental and social aspects required by the Accounts Modernisation Directive (Dumitru et al., 2017).

Spontaneous convergence was found in certain instances, for example, when Italy and France specified information related to employees.

However, numerous differences also exist. Differences emerge in how each country made sense of the non-financial matters above. The UK doesn't almost provide any further specification, while the French regulation enters quite in detail in terms of information to be provided in relation to each of the topic. This means that making a sound comparison of ESG politics and performance data of France companies with UK ones may be a difficult task to accomplish. Differences exist also in relation to clarity of information. All countries require companies to explain why policies are not pursued as required by the NF Directive, but France doesn't require the non-financial statement to include, where appropriate, additional explanations of and references to financial statements.

Generally speaking, the UK is the country that regulated the least, almost following a copying-out approach. This may be due to obligations existing before the NF Directive, the One in-Two out Rule, but also the typical delegation of issuing more stringent and detailed requirements to the profession (Evans and Nobes, 1998).

Conversely, the Italian decree went beyond some of the requirements. In Italy, going beyond a minimum-compliance approach could indicate that the country 
welcomed the misfit (Falkner et al, 2007). Indeed, regulation could be an opportunity as the Danish and French case demonstrates (Danish Business Authority, 2013; KPMG, 2011).

France used the most intrusive regulatory intervention. Discretion was used to add requirements where no options were given. France also enlarged the company scope of application of the regulation, ultimately jeopardizing comparability.

Country differences emerged where the NF Directive was silent (i.e., when Italy required the disclosure of changes in policies to foster comparability and decided to set penalties to have a positive effect on current practices) as well as when the NF Directive left Member States the flexibility to adopt or not a certain provision (for example, whether to use the management report or a separate report).

One of the most interesting differences refers to the audit on the presence and content of the non-financial statement. France seems to have gone the furthest in terms of reliability of the information as it sets more stringent requirements on the assurance than the other countries, but it allows for a wide range of assurance providers other than auditing firms. Who conducts assurance may impact the credibility of the information perceived by the investors (Pflugrath et al., 2011). Not requiring the assurance of the content in the UK may similarly hinder the credibility of the induration provided.

This result raises a question about the appropriateness for the EU to leave discretion in relation to certain crucial aspects rather than about the implementation choice of the individual Member States. Making some further aspect mandatory (e.g., auditing of the information) would have not necessarily disregarded the overall intention to follow a "one-size-fits-all" approach (EC, 2017) and facilitated the achievement of the NF objectives (e.g., trust).

The future analysis of the first non-financial statements will help appreciate how companies actually responded and the extent of the change. After analyzing material implementation, it is possible that the EU will eventually reduce the flexibility of actions. Thus, the Directive can be interpreted as a first step to provide insights about whether a more stringent EU approach is needed. However, pushing toward standardization can be a double-edged sword as it could impact the relevance of information.

\section{Bibliography}

Aisbitt, S. (2008). Implementation of Supra-national Policies: Lessons from the Nordic Countries' Experiences of European Directives, Accounting History, 13 (1), 75-99.

http://dx.doi.org/10.1177/1032373207083927

Albareda, L., Lozano, J. M., \& Ysa, T. (2007). Public Policies on Corporate Social Responsibility: the Role of Governments in Europe, Journal of Business Ethics, 74 (4), 391-407.

http://dx.doi.org/10.1007/s10551-007-9514-1

Arnold, A. J., \& Matthews, D. R. (2002). Corporate Financial Disclosures in the UK, 1920-50: The Effects of Legislative Change and Managerial Discretion, Accounting and Business Research, 32 (1), 3-16. http://dx.doi.org/10.1080/00014788.2002.9728951

Baker, C. R. (2014). A Comparative Analysis of the Development of the Auditing Profession in the United Kingdom and France, Accounting History, 19 (1-2), 97-114.

http://dx.doi.org/10.1177/1032373213513555 
Ball, R., Robin, A., \& Wu, J. (2003). Incentives versus Standards: Properties of Accounting Income in Four East Asian Countries, Journal of Accounting \& Economics, 36, 235-270.

http://dx.doi.org/10.1016/i.jacceco.2003.10.003

Barak, A. (2005). Purposive Interpretation in Law, Princeton, Princeton University Press.

Baratta, R., \& Carli, L. G. (2014). Complexity of EU Law in the Domestic Implementing Process. Accessed on 09/04/2018 from http://ec.europa.eu/dgs/legal_service/seminars/20140703 baratta_speech.pdf

Barth, M. E., \& Schipper, K. (2008). Financial Reporting Transparency, Journal of Accounting, Auditing \& Finance, 23 (2), 173-190. http://dx.doi.org/10.1177/0148558X0802300203

Bebbington, J., Kirk, E. A., \& Larrinaga, C. (2012). The Production of Normativity: A Comparison of Reporting Regimes in Spain and the UK, Accounting, Organizations and Society, 2 (37), 7894.

http://dx.doi.org/10.1016/j.aos.2012.01.001

Bernardi, C., \& Stark, A. W. (2016). Environmental, Social and Governance Disclosure, Integrated Reporting, and the Accuracy of Analyst Forecasts, The British Accounting Review, 1-16. http://dx.doi.org/10.1016/j.bar.2016.10.001

Boiral, O. (2013). Sustainability Reports as Simulacra? A Counter-Account of A and A+ GRI Reports, Accounting, Auditing \& Accountability Journal, 26 (7), 1036 - 1071.

http://dx.doi.org/10.1108/AAAJ-04-2012-00998

Bolivar, P. M. R. (2009.) Evaluating Corporate Social and Environmental Reporting on the Internet: the Utilities and Resource Industries in Spain, Business and Society, 48 (2), 179-205. http://dx.doi.org/10.1177/0007650307305370

Borzel, T. A. (2003). Environmental Leaders and Laggards in Europe: Why there is (not) a 'Southern Problem', Aldershot, Ashgate.

Borzel, T. A., \& Risse, T. (2003). Conceptualizing the Domestic Impact of Europe, The Politics of Europeanization, 57-80. http://dx.doi.org/10.1093/0199252092.003.0003

Boston, J., \& Lempp, F. (2011). Climate Change: Explaining and Solving the Mismatch between Scientific Urgency and Political Inertia, Accounting, Auditing \& Accountability Journal, 24 (8), 1000-102.

http://dx.doi.org/10.1108/09513571111184733

Boyer-Allirol, B. (2013). Faut-il mieux réglementer le reporting extrafinancier?, Revue française de gestion, 2013/8, n. 237, 73-95.

http://dx.doi.org/10.3166/RFG.237.73-95

Brondoni, S. M. (2014). Global Capitalism and Sustainable Growth. From Global Products to Network Globalisation, Symphonya. Emerging Issues in Management (symphonya.unimib.it), 1, $10-31$. http://dx.doi.org/10.4468/2014.1.02brondoni

Bursens, P. (2002). Why Denmark and Belgium Have Different Implementation Records: On Transposition Laggards and Leaders in the EU, Scandinavian Political Studies, 25 (2), 173-195. http://dx.doi.org/10.1111/1467-9477.00068

Bushman, R.M., Piotroski, J.D., \& Smith, A.J. (2004). What Determines Corporate Transparency?, Journal of Accounting Research, 42 (2), 207-252.

http://dx.doi.org/10.1111/j.1475-679X.2004.00136.x

Cantino, V., \& Cortese, D. (2017). Integrated Report System in Italian Law, Symphonya. Emerging Issues in Management (symphonya.unimib.it), 1, 83-94. http://dx.doi.org/10.4468/2017.1.07cantino.cortese

Chauvey, J. N., Giordano-Spring, S., Cho, C., \& Patten, D. (2015). The Normativity and Legitimacy of CSR Disclosure: Evidence from France, Journal of Business Ethics, 130 (4), 789-803. http://dx.doi.org/10.1007/s10551-014-2114-y 
Chelli M., Richard, J., \& Durocher, S. (2014). France's New Economic Regulations: Insights from Institutional Legitimacy Theory, Accounting Auditing \& Accountability Journal, 27 (2), 283-316. http://dx.doi.org/10.1108/AAAJ-07-2013-1415

Cho, S. Y., Lee, C., \& Pfeiffer, R. J. (2013). Corporate Social Responsibility Performance and Information Asymmetry, Journal of Accounting and Public Policy, 32, 71-83. http://dx.doi.org/10.1016/j.jaccpubpol.2012.10.005

Cohen, R., Holder-Webb, L., \& Zamora, V. L. (2015). Nonfinancial Information Preferences of Professional Investors, Behavioral Research in Accounting: Fall, 27 (2), 127-153. http://dx.doi.org/10.2308/bria-51185

Cole, V., Branson, J., \& Breesch, D. (2012) The Uniformity-Flexibility Dilemma when Comparing Financial Statements: Views of Auditors, Analysists and other Users, International Journal of Accounting and Information Management, 20 (2), 114-128. http://dx.doi.org/10.1108/18347641211218443

Contrafatto, M., \& Rusconi, G. (2005). Social Accounting in Italy: Origins and Developments, Social and Environmental Accountability Journal, 25 (2), 3-8. http://dx.doi.org/10.1080/0969160X.2005.9651737

CorporateRegister (2008). Assure View: The CSR Assurance Statement Report. Accessed on 06/04/2018 from https://www.corporateregister.com/pdf/AssureView.pdf

d'Arcy, A. (2001). Accounting Classification and the International Harmonisation Debate - an Empirical Investigation, Accounting, Organizations and Society, 26, 327-349. http://dx.doi.org/10.1016/S0361-3682(00)00036-2

Danish Business Authority (2013). Impact of the Third Year Subject to the Legal Requirements for Reporting on CSR in the Danish Financial Statements Act. Accessed on 08/04/2018 from http://csrgov.dk/file/358879/csr_rapport_2013_eng.pdf.

Davis, C. E., Clements, C., \& Keuer, W. P. (2003). Web-based Reporting: a Vision for the Future. Strategic Finance, September, 45-49.

De Villiers, C., \& Van Staden, C. J. (2010). Shareholders' Requirements for Corporate Environmental Disclosures: a Cross Country Comparison, The British Accounting Review, 42 (4), 227-240.

http://dx.doi.org/10.1016/j.bar.2010.08.002

De Villiers, C., \& Van Staden, C. J. (2012). New Zealand Shareholder Attitudes towards Corporate Environmental Disclosure, Pacific Accounting Review, 24 (2), 186-210. http://dx.doi.org/10.1108/01140581211258470

Dhaliwal, D., Li, O. Z., Tsang, A., \& Yang, G. Y. (2011). Voluntary Nonfinancial Disclosure and the Cost of Equity Capital: The Initiation of Corporate Social Responsibility Reporting, The Accounting Review, 86, 59-100.

http://dx.doi.org/10.2308/accr.00000005

Dimitrakopoulos, D. (2001). The Transposition of EU Law: 'Post-Decisional Politics' and Institutional Autonomy, European Law Journal, 7 (4), 442 - 458.

http://dx.doi.org/10.1111/1468-0386.00137

Dimitrova, A., \& Steunenberg, B. (2000). The Search for Convergence of National Policies in the European Union: an Impossible Quest? European Union Politics, 1 (2), 201-226.

http://dx.doi.org/10.1177/1465116500001002003

Dubbnik, G. W, Graafland, J. J, \& Liederkerke, L. (2008). CSR, Transparency and the Role of Intermediate Organizations, MPRA Paper, No. 17892, Accessed on 27/04/2018 from https://core.ac.uk/download/pdf/12021402.pdf

Dumitru, M., Dyduch, J., Gușe, R-G., \& Krasodomska, J. (2017). Corporate Reporting Practices in Poland and Romania - An Ex-ante Study to the New Non-financial Reporting European Directive, Accounting in Europe, 14 (3), 279-304. http://dx.doi.org/10.1080/17449480.2017.1378427

EC (2011). Summary Report on the Responses Received to Public Consultation on Disclosure of Non-financial Information by Companies. Accessed on 27/04/2018 from http://ec.europa.eu/finance/consultations/2010/non-financial-reporting/index_en.htm

EC (2013). Impact Assessment. Accessed on 06/04/2018 from https://eur-lex.europa.eu/legalcontent/EN/TXT/?uri=CELEX\%3A52013SC0127 
EC (2016). Report from the Commission 2016. EU-28 countries factsheet on monitoring the application of EU law. Accessed on 08/05/2018 from https://ec.europa.eu/info/publications/2016eu-28-countries-factsheet-monitoring-application-eu-law_en

EC (2017). Communication from the Commission (2017/C 215/01). Guidelines on Non-financial Reporting (Methodology for Reporting Non-financial Information). Accessed on 08/04/2018 from https://eur-lex.europa.eu/legal-content/EN/TXT/PDF/?uri=CELEX:52017XC0705(01)\&from=EN

Evans, L., \& Nobes, C. (1998). Harmonization Relating to Auditor Independence the Eight Directive the UK and Germany, European Accounting Review, 7 (3), 493-516.

http://dx.doi.org/10.1080/096381898336394

EY (2014). Sustainability Reporting - The Time is now. Accessed on 05022018 from http://www.ey.com/Publication/vwLUAssets/EY_Sustainability reporting the time is now/\$FILE/EY-Sustainability-reporting-the-time-is-now.pdf.

Falkner, G., Hartlapp, M., \& Treib, O. (2007). Worlds of Compliance: Why Leading Approaches to European Implementation Are Only "Sometimes-True Theories", European Journal of Political Research, 64 (3), 395-476. http://dx.doi.org/10.1111/j.1475-6765.2007.00703.x

Frias-Aceituno, J. V., Rodriguez- Ariza, L., \& Garcia-Sanchez, I. M. (2013). The Role of the Board in the Dissemination of Integrated Corporate Social Reporting. Corporate Social Responsibility and Environmental Management, 20, 219-233.

http://dx.doi.org/10.1002/csr.1294

Goss, A., \& Roberts, G. S. (2011). The Impact of Corporate Social Responsibility on the Cost of Bank Loans, Journal of Banking and Finance, 35, 1794-1810.

http://dx.doi.org/10.1016/j.jbankfin.2010.12.002

Green-Cowles, M., Caporaso, J., \& Risse, T. (2001). Transforming Europe. Europeanization and Domestic Change, Ithaca, Cornell University Press.

GRI (2011), Sustainability Reporting Guidelines. Accessed from https://www.globalreporting.org/resourcelibrary/G3.1-Guidelines-Incl-Technical-Protocol.pdf

Hamann, R. (2004). Corporate Social Responsibility, Partnerships, and Institutional Change: The Case of Mining Companies in South Africa, Natural Resources Forum, 28 (4), 278-290.

http://dx.doi.org/10.1111/j.1477-8947.2004.00101.x

Heritier, A. (1995). "Leaders" and "Laggards" in European Clean Air Policy, in van Waarden, F., \& Unger, B. (eds), Convergence or Diversity? Internationalization and Economic Policy Response, Aldershot, Avebury, 278-305.

Hibbitt, C., \& Collison, D. (2004). Corporate Environmental Disclosure and Reporting Developments in Europe, Social and Environmental Accountability Journal, 24 (1), 1-11. http://dx.doi.org/10.1080/0969160X.2004.9651708

Hunton, J. E., Libby, R., \& Mazza, C. L. (2006). Financial Reporting Transparency and Earnings Management, The Accounting Review, 81 (1), 135-157.

http://dx.doi.org/10.2308/accr.2006.81.1.135

IFAC (2012). Investor Demand for Environmental, Social, and Governance Disclosures: Implications for Professional Accountants in Business. Accessed on 27/12/2017 from http://html5.epaperflip.com/?docid=468a0de8-61e2-4345-b46f-a56000f70849\#page=0

Jeffery, C. (2017). Comparing the Implementation of the EU Non-Financial Reporting Directive in the UK, Germany, France and Italy. Accessed on 01/03/20188 from http://ssrn.com/abstract=3083368

Jeppesen, K. J, \& Loft, A. (2011). Regulating Audit in Europe: The Case of the Implementation of the EU Eighth Directive in Denmark 1984-2006, European Accounting Review, 20 (2), 321-354. http://dx.doi.org/10.1080/09638180.2010.493652

Johansen, T. R. (2016). EU Regulation of Corporate Social and Environmental Reporting, Social and Environmental Accountability Journal, 36 (1), 1-9.

http://dx.doi.org/10.1080/0969160X.2016.1148948 
Knill, C., \& Lenschow, A. (1998). Coping with Europe: the Impact of British and German Administrations on the Implementation of EU Environmental Policy, Journal of European Public Policy, 5 (4), 595-614. http://dx.doi.org/10.1080/13501769880000041

KPMG (2011). International Survey of Corporate Responsibility Reporting 2011. Accessed on 04/04/2018 from https://home.kpmg.com/xx/en/home/insights.html

KPMG (2013). The KPMG Survey of Corporate Responsibility Reporting 2013. Accessed on 05/02/2018 from https://assets.kpmg.com/content/dam/kpmg/pdf/2015/08/kpmg-survey-ofcorporate-responsibility-reporting-2013.pdf.

Leuz C. (2010). Different Approaches to Corporate Reporting Regulation: How Jurisdictions differ and Why, Accounting and Business Research, 40 (3), 229-256. http://dx.doi.org/10.1080/00014788.2010.9663398

Lewis, L., \& Unerman, J. (1999). Ethical Relativism: a Reason for Differences in Corporate Social Reporting?, Critical Perspective on Accounting, 10, 521-547.

http://dx.doi.org/10.1006/cpac.1998.0280

Luque-Vilchez, M., \& Larrinaga, C. (2016). Reporting Models do not Translate Well: Failing to Regulate CSR Reporting in Spain, Social and Environmental Accountability Journal, 36 (1), 5675.

http://dx.doi.org/10.1080/0969160X.2016.1149301

Mahoney, P. (2009). The Development of Securities Law in the United States, Journal of Accounting Research, 47 (2), 325-347.

http://dx.doi.org/10.1111/j.1475-679X.2009.00326.x

Mastenbroek, E. (2003). Surviving the Deadline. The Transposition of EU Directives in the Netherlands, European Union Politics, 4 (4), 371-395.

http://dx.doi.org/10.1177/146511650344001

Matuszak, Ł., \& Różańska, E. (2017). CSR Disclosure in Polish-Listed Companies in the Light of Directive 2014/95/EU Requirements: Empirical Evidence, Sustainability, 9, 2304, 1-18.

http://dx.doi.org/10.3390/su9122304

McEwen, R. A. (2009). Transparency in Financial Reporting: A Concise Comparison of IFRS and US GAAP, Petersfield, Harriman House Ltd.

Merkl-Davies, D. M., \& Brennan, N. M. (2007). Discretionary Disclosure Strategies in Corporate Narratives: Incremental Information or Impression Management?, Journal of Accounting Literature, 26, 116-96. Accessed on 27/04/2018 from http://hdl.handle.net/10197/2907

Michelon, G., Pilonato, S., \& Ricceri, F. (2015). CSR Reporting Practices and the Quality of Disclosure: an Empirical Analysis, Critical Perspectives on Accounting, 33, 59-78.

http://dx.doi.org/10.1016/j.cpa.2014.10.003

Mulford, C. W., \& Comiskey, E. E. (2002). The Financial Numbers Game: Detecting Creative Accounting Practices, New Jersey, John Wiley \& Sons Inc.

Pflugrath, G., Roebuck, P., \& Simnett, R. (2011). Impact of Assurance and Assurer's Professional Affiliation on Financial Analysts' Assessment of Credibility of Corporate Social Responsibility Information, Auditing: A Journal of Practice and Theory, 30 (3), 239-254.

http://dx.doi.org/10.2308/ajpt-10047

Rahman, A., Perera, H., \& Ganesh, S. (1996). Measurement of Formal Harmonisation in Accounting: an Exploratory Study, Accounting and Business Research, 26 (4), 325-339. http://dx.doi.org/10.1080/00014788.1996.9729522

Roohani, S., Furusho, Y., \& Koizumi, M. (2009). XBRL: Improving Transparency and Monitoring Functions of Corporate Governance, International Journal of Disclosure and Governance, 6 (4), 355-369. http://dx.doi.org/10.1057/jdg.2009.17

Salvioni D. M, \& Bosetti, L. (2014). Sustainable Development and Corporate Communication in Global Markets, Symphonya. Emerging Issues in Management (symphonya.unimib.it), 1, 32 - 51. http://dx.doi.org/10.4468/2014.1.03salvioni.bosetti

Simnett, R., Nugent, M., \& Huggins, A. L. (2009). Developing an International Assurance Standard on Greenhouse Gas Statements, Accounting Horizons, 23 (4), 347-363. 
(C) SYMPHONYA Emerging Issues in Management, n. 1, 2018

symphonya.unimib.it

http://dx.doi.org/10.2308/acch.2009.23.4.347

Stone, G., Joseph, M., \& Blodgett, J. J. (2004). Toward the Creating of an Eco-Oriented Corporate Culture: A Proposed Model of Internal and External Antecedents Leading to Industrial Firm EcoOrientation, The Journal of Business and Industrial Marketing, 19 (1), 68-84. http://dx.doi.org/10.1108/08858620410516754

Szabó, D. G., \& Sørensen, K. E. (2017). Non-financial Reporting, CSR Frameworks and Groups of Undertakings: Application and Consequences, Journal of Corporate Law Studies, 17 (1), 137-165. http://dx.doi.org/10.1080/14735970.2016.1254449

Tay, J. S. W., \& Parker, R. H. (1990). Measuring International Harmonization and Standardization, Abacus, 26 (1), 71-88.

http://dx.doi.org/10.1111/j.1467-6281.1990.tb00233.x

UN (2013). The UN Global Compact-Accenture CEO Study on Sustainability 2013. Accessed on 27/12/2017 from http://www.unglobalcompact.org/docs/news_events/8.1/UNGC_Accenture_CEO_Study_2013.pdf

UNEP (2010). Carrots and Sticks - Promoting Transparency and Sustainability. Accessed on 05/02/2018 from https://www.globalreporting.org/resourcelibrary/Carrots-And-Sticks-PromotingTransparency-And-Sustainbability.pdf

Versluis, E. (2007). Even Rules, Uneven Practices: Opening the 'Black Box' of EU Law in Action, West European Politics, 30 (1), 50-67. http://dx.doi.org/10.1080/01402380601019647

Walton, P. (1992). Harmonisation of Accounting in France and Britain: Some Evidence, Abacus, 28 (2), 186-99.

http://dx.doi.org/10.1111/j.1467-6281.1992.tb00279.x

Wolk H. I., Dodd J. L., \& Rozycki, J. J. (2008). Accounting Theory: Conceptual Issues in a Political and Economic Environment, Los Angeles, Sage. 